\title{
The Efficacy of Semiselective Chemicals and Chloropicrin/1, 3-Dichloropropene-Containing Fumigants in Managing Apple Replant Disease in South Africa
}

\author{
M. Nyoni, ${ }^{1}$ M. Mazzola, ${ }^{1,2}$ J. P. B. Wessels, ${ }^{3}$ and A. McLeod $^{1 \dagger}$ \\ ${ }^{1}$ Department of Plant Pathology, Stellenbosch University, Matieland 7600, South Africa; ${ }^{2}$ Tree Fruit Research Laboratory, U.S. \\ Department of Agriculture Agricultural Research Service, Wenatchee, WA 98801, U.S.A.; and ${ }^{3}$ ProCrop, Somerset West 7130 , \\ South Africa
}

\begin{abstract}
Apple replant disease (ARD) is a biological phenomenon that is encountered when old apple orchards are replanted, resulting in tree growth and yield reductions in young trees. Three ARD orchard trials were conducted, which showed that semiselective chemicals (fenamiphos, metalaxyl, imidacloprid, and phosphonates) used independently, two fumigant formulations (33.3\% chloropicrin and 60.8\% 1,3-dichloropropene [Pic33-1,3D] and $57 . \%$ chloropicrin and 38\% 1,3 dichloropropene [Pic57-1,3D]), and semiselective chemicals combined with Pic33-1,3D or Pic57-1,3D all contributed to significant increases in tree growth (trunk diameter and shoot length) relative to the untreated control 3 to 4 years postplanting. The treatments did not differ significantly from each other in improving tree growth. Yield was more indicative of treatment efficacy, but this varied between the three orchards. The Pic33-1,3D fumigant in combination with semiselective chemistries was the most consistent in significantly increasing cumulative yields. The Pic57-1,3D treatment was superior in increasing yields relative to the Pic33-1,3D treatment, because (i) it significantly increased

obtained with Pic57-1,3D relative to the control treatment but not with the Pic33-1,3D treatment. The quantification of ARD causative agents 20 months postplant showed that Phytophthora cactorum contributed to disease development in all three orchards; significant negative correlations existed between the quantity of $P$. cactorum DNA detected in tree roots and tree growth and less often, yield. In two orchards, only some of the treatments that significantly reduced the quantity of $P$. cactorum DNA in tree roots relative to the control also resulted in a significant increase in tree growth. Some of the aforementioned trends were also evident for Pratylen chus spp. root densities in two of the orchards. There was a significant positive correlation between $P$. cactorum root DNA quantities and Pratylenchus spp. root densities. Pythium spp. and "Cylindrocarpon"-like DNA quantities detected in tree roots typically were not indicative of treatment efficacy. However, a significant positive correlation existed between these two pathogen groups, suggesting complex interactions not associated with pathogen quantities per se.
\end{abstract} cumulative yields in comparison with the Pic33-1,3D treatment in one orchard and (ii) in another orchard, a significant increase in yield was
Keywords: causal agent, oomycetes, potassium phosphonate
Apple replant disease (ARD) is a root disease of apples (Malus $\times$ domestica Borkh.) that occurs when apple is replanted on soil previously planted to apple or related species. It is a soilborne disease that causes tree stunting and delayed apple fruit bearing (Mazzola and Manici 2012). Up to a 50\% loss in orchard lifespan productivity and profitability can be incited by ARD (Rabie et al. 2001). The biological agents involved in ARD consist of a wide spectrum of organisms, including fungi, nematodes, and oomycetes. The occurrence or relative abundance of individuals that make up the causal pathogen complex can vary across ARD orchard sites (Manici et al. 2003; Mazzola 1998; Tewoldemedhin et al. 2011c).

The ARD causative agents are mostly similar worldwide, whereas some are absent or differ in species composition in South Africa. Pratylenchus spp. are known as causal agents of ARD worldwide (Dullahide et al. 1994; Jaffe et al. 1982b; Mazzola 1998; Stirling et al. 1995; Tewoldemedhin et al. 2011b). Although the multinucleates Rhizoctonia solani J. G. Kühn AG-5 and/or Rhizoctonia solani J. G. Kühn

${ }^{\dagger}$ Corresponding author: A. McLeod; adelem@sun.ac.za

Funding: We thank the South African Apple and Pear Producer's Association and the Technology and Human Resources for Industry Programme for funding the project.

*The $\boldsymbol{e}$-Xtra logo stands for "electronic extra" and indicates that one supplementary table is published online.

The author(s) declare no conflict of interest.

Accepted for publication 21 December 2018.

C 2019 The American Phytopathological Society
AG-6 are highly virulent pathogens in the United States and Italy (Manici et al. 2003; Mazzola 1997), these agents have not been identified in South African ARD orchards. South African ARD orchard soils do contain binucleate Rhizoctonia anastomosis groups which have also been identified in other countries. The binucleate isolates can have a range of pathogenic to nonpathogenic interactions with apple (Manici et al. 2003; Mazzola 1997; Tewoldemedhin et al. 2011b). Manici et al. (2013) hypothesized that binucleate Rhizoctonia spp. and Fusarium spp. have a commensal or mutual symbiotic relationship with apple trees rather than a pathogenic relationship. "Cylindrocarpon"-like fungi can have a range of neutral or negative interactions with apple, although most isolates were found to be nonpathogenic to mildly virulent toward apple in different regions of the world (Braun 1991, 1995; Dullahide et al. 1994; Jaffee et al. 1982a; Manici et al. 2003, 2018; Mazzola 1998; Tewoldemedhin et al. 2011a). The taxonomy of Cylindrocarpon-like fungi has undergone major revisions, including changes in genus and species names (Cabral et al. 2012; Chaverri et al. 2011; Lombard et al. 2014). For the purpose of this study, reference will only be made to Cylindrocarpon-like fungi. In South Africa, selected oomycetes in the genera Phytophthora and Pythium, which occur worldwide, play an important role in ARD based on their widespread occurrence and high virulence toward apple (Tewoldemedhin et al. 2011b, 2011c).

Because of the complex composition of ARD causative agents, preplant broad-spectrum soil fumigants are the primary measure used to manage the disease. Chloropicrin combined with 1,3-dichloropropene is currently the most commonly used fumigant for the control of ARD (Cabrera et al. 2015; Mazzola and Manici 2012; Mazzola et al. 2015; Yao et al. 2006). The ratio of these two chemistries differs among fumigant products depending on whether the target organisms are fungi or nematodes. Chloropicrin mainly has a fungicidal activity, whereas 1,3-dichloropropene targets nematodes (Cabrera et al. 
2015; Locascio et al. 1997). Preplant orchard soil fumigation is primarily limited to application in the planting row rather than the entire orchard block, which limits the overall treatment cost. Therefore, the fumigation effect is relatively short lived, likely as a result of rapid recolonization of fumigated soils from the untreated interrows (Mazzola et al. 2015). Nonetheless, fumigation is effective in managing ARD, because it allows for sufficient plant protection during the initial 1 to 2 years after orchard establishment when young apple trees exhibit significantly elevated growth suppression resulting from root infection by ARD causative agents in comparison with older trees (Mazzola and Manici 2012; Mazzola et al. 2015).

The use of systemic chemicals, including phosphonates, phenylamides, and fenamiphos, may have potential as tools for managing ARD in South Africa, because these pesticides target two of the majorARD causative agent groups: oomycetes and nematodes. Phosphonates and the phenylamides metalaxyl and mefenoxam (containing only the active R-enantiomer of metalaxyl) were reported to control Phytophthora cactorum (Lebert \& Cohn) J. Schröon on apple under orchard conditions (Utkhede 1987; Utkhede and Smith 1995). Several pathogenic Pythium spp. associated with ARD were shown to be sensitive to metalaxyl in vitro (Mazzola et al. 2002). Autio et al. (1991) showed that the application of metalaxyl to an ARD site resulted in a significant increase in tree trunk and shoot growth but only in the first year of growth. The nematicidal activity of fenamiphos is well known, and the compound is registered for managing Pratylenchus spp. on nonbearing apple trees in South Africa. However, in several countries, excluding South Africa, it is no longer available because of environmental concerns (Wesseling et al. 2005).

The main aims of this study were to evaluate in three orchard trials (i) whether two fumigants varying in their ratio of chloropicrin/ 1,3-dichoropropene differed in ARD control efficacy and (ii) if semiselective chemicals (fenamiphos, metalaxyl, phosphonate, and imidacloprid) applied independently or in concert with soil fumigation could be used to manage ARD in South Africa. Because methyl bromide was only phased out in January 2015 in South Africa (Kapp et al. 2016), this treatment was also included in two of the trials to provide apple growers with information regarding the performance of new fumigants in comparison with the conventional fumigation treatment. To better understand the basis for treatment performance, the prevalence of a few ARD marker microbial pathogens (Cylindrocarpon-like fungi, $R$. solani AG-5, the genus Phytophthora, Pythium ultimum Trow, Pythium irregulare Buisman, Pythium sylvaticum W. A. Campb. \& F. F. Hendrik, and Phytopythium vexans [de Bary] Abad, de Cock, Bala, Robideau, Lodhi \& Levesque) and parasitic nematodes (Pratylenchus spp.) were monitored in orchard tree roots. A glasshouse apple seedling bioassay trial was conducted to gain additional insight into the identity of oomycete ARD causative agents involved and the relative potential for ARD development in the orchard soils.

\section{Materials and Methods}

Orchard trials. Orchard sites. ARD trials were conducted at three orchard sites (Grabouw [GRA], Witzenberg valley [WZB], and the Koue Bokkeveld [KBC]) situated in the Western Cape Province of
South Africa (Table 1). The region is characterized by a Mediterranean climate with cool, wet winters and warm, dry summers. The orchards were located in three different production regions. The orchard history of each of the orchards before planting is presented in Table 1. Orchards GRA and WZB were planted in 2013, and orchard KBC was planted in 2014. The orchards contained the M.793 or M.7 rootstocks grafted with Royal Beaut or the MM.109 rootstock and Early red one scion. All orchards had microsprinkler irrigation systems, whereas the row and tree spacing varied in the orchards (Table 1). Fertilization was conducted using standard grower practices. The soil type, $\mathrm{pH}$, resistance and cation exchange capacity, and water holding capacity of each orchard soil are shown in Table 2. Orchards WZB and KBC had sandy loam soils, whereas Orchard GRA had a clay loam soil type (Table 2).

Trial treatments and design. The following treatments were applied in orchards GRA and WZB:

(i) untreated control,

(ii) preplant fumigation with $33.3 \%$ chloropicrin and $60.8 \% 1,3-$ dichloropropene [Pic33-1,3D],

(iii) preplant fumigation with $57.0 \%$ chloropicrin and $38.0 \%$ 1,3dichloropropene [Pic57-1,3D],

(iv) semiselective chemicals (fenamiphos, imidacloprid, metalaxyl, and potassium phosphonate; independent semiselectives),

(v) preplant fumigation with Pic33-1,3D plus semiselective chemicals (Pic33-1,3D/semiselectives), and

(vi) methyl bromide.

In orchard $\mathrm{KBC}$, the same treatments were applied as in orchards GRA and WZB except that the methyl bromide treatment was replaced with a treatment consisting of preplant fumigation with Pic57-1,3D combined with semiselective chemicals (Pic57-1,3D/ semiselectives).

The fumigation treatments (Pic57-1,3D, Pic33-1,3D, and methyl bromide) were applied to the orchard rows before planting (12- to 20 -m-long $\times 80$ - to 100 -cm-wide plots) through shank injection (40-cm dept) followed by immediate tarping with impermeable black plastic for a period of at least 2 weeks. Fumigants were applied by a registered pesticide applicator (BioScience Research CC). Methyl bromide $(980 \mathrm{~g} / \mathrm{kg}$ methyl bromide and $20 \mathrm{~g}$ chloropicrin per $1 \mathrm{~kg}$; Mebrom Chemicals) was applied at $50 \mathrm{~g} / \mathrm{m}^{2}$. The two different Pic-1,3-D formulations were applied at a dosage of $52 \mathrm{~g} / \mathrm{m}^{2}$. The two Pic33-1,3D formulations consisted of the products Agrocelone NE (Pic33-1,3D; Agroquimicos de levanter) and Agrocelone FE (Pic57-1,3D; Agroquimicos de levanter).

The semiselectives mixture consisted of the application of four pesticides, including metalaxyl, fenamiphos, imidacloprid, and phosphonates. Metalaxyl, fenamiphos, and imidacloprid were applied as a soil drench at planting followed by four to five sets of phosphonate applications over a 3-year period. The soil drench was applied shortly after planting when trees started budding and showed clear signs of growth initiation. The soil drench was applied as a 2-liter drench per tree, which contained $1.05 \mathrm{~g}$ imidacloprid (Confidor $70 \mathrm{WG}$; Bayer; 700 a.i. g/kg), $1 \mathrm{~g}$ fenamiphos (Nemacur 400 EC; Villa Crop Protection; $400 \mathrm{~g}$ a.i./liter), $2 \mathrm{~g}$ metalaxyl, and $12 \mathrm{~g}$ mancozeb (Metazeb $700 \mathrm{WP}$; Villa Crop Protection; $100 \mathrm{~g} / \mathrm{kg}$ metalaxyl and

Table 1. Agronomic information of apple orchards that were used in apple replant disease management trials

\begin{tabular}{|c|c|c|c|c|c|c|c|c|}
\hline $\begin{array}{l}\text { Orchard } \\
\text { name }\end{array}$ & $\begin{array}{l}\text { Production } \\
\text { region }\end{array}$ & $\begin{array}{l}\text { History of old orchard that } \\
\text { was removed (age, cultivar } \\
\text { and rootstock, and year of } \\
\text { orchard removal) }\end{array}$ & Fumigation date & Planting date & Rootstock & Variety & $\begin{array}{l}\text { Row } \times \text { tree } \\
\text { spacing, } \mathbf{m}\end{array}$ & $\begin{array}{c}\text { Irrigation } \\
\text { type }\end{array}$ \\
\hline GRA & Grabouw & $\begin{array}{l}36 \text { years, cultivars Granny } \\
\text { Smith and Golden delicious } \\
\text { on seedling rootstocks, } 2010\end{array}$ & $\begin{array}{l}\text { 16 September } \\
2013\end{array}$ & 3 October 2013 & M.7 & Royal Beaut & $4.5 \times 2$ & $\begin{array}{l}\text { Microsprinkler } \\
\text { irrigation }\end{array}$ \\
\hline WZB & Witzenberg valley & $\begin{array}{c}53 \text { years, cultivars Golden } \\
\text { delicious and Starking on } \\
\text { seedling rootstock, } 2013\end{array}$ & $\begin{array}{l}\text { 10 September } \\
2013\end{array}$ & $\begin{array}{l}12 \text { October } \\
2013\end{array}$ & MM.109 & Early red one & $3.75 \times 1.25$ & $\begin{array}{l}\text { Microsprinkler } \\
\text { irrigation }\end{array}$ \\
\hline $\mathrm{KBC}$ & Koue Bokkeveld & $\begin{array}{l}18 \text { years, cultivar Braestars on } \\
\text { M793, } 2013\end{array}$ & $\begin{array}{l}13 \text { September } \\
2014\end{array}$ & 6 October 2014 & M.793 & Royal Beaut & $4 \times 1.5$ & $\begin{array}{l}\text { Microsprinkler } \\
\text { irrigation }\end{array}$ \\
\hline
\end{tabular}


$600 \mathrm{~g} / \mathrm{kg}$ mancozeb). Metazeb is a cost-effective metalaxyl formulation currently used by growers. The alternative new formulations to Metazeb that do not contain mancozeb are more expensive, because they only contain mefenoxam, which is the active enantiomer of metalaxyl.

At the GRA and WZB orchards, the first set of potassium phosphonate (Phosguard $400 \mathrm{SL} ; 400 \mathrm{~g}$ a.i./L) applications was made in December 2013 (3 months after planting), which consisted of three foliar sprays ( $50 \mathrm{ml}$ of $2 \mathrm{~g}$ a.i./liter per tree) applied at 1-week intervals. The second set of phosphonate applications was applied as a trunk paint $(50 \mathrm{ml}$ of $200 \mathrm{~g}$ a.i./liter solution per tree) in the second year of growth in October 2014 just after bud break ( 13 months after planting). Trunk paint application was used, because leaves are required for foliar applications. The same dosage and frequency of applications were used for all subsequent phosphonate foliar and trunk paint treatments. The third set of phosphonate applications consisted of three foliar sprays conducted in December 2014. The fourth and fifth phosphonate application sets were made in the third year of growth and consisted of a trunk paint application in October 2015 followed by three foliar sprays conducted in December 2015 . Foliar applications were made using a motorized mist blower backpack sprayer (SR 400; STIHL), and trunk paints were applied with a paintbrush from the soil surface upward onto stems $(\sim 30 \mathrm{~cm})$. For orchard $\mathrm{KBC}$, the phosphonate applications were made using the same methods and timing of application as for orchards GRA and WZB, except that all applications were made 1 year later, because the trial was planted 1 year after the GRA and WZB trials.

In all three orchards, treatments were replicated six times in a completely randomized design. Each replicate consisted of 10 trees.

Trial evaluations. Tree growth. All tree growth measurements were made on the center 8 trees of each 10 -tree replicate. Tree growth was evaluated by determining shoot length and the increase in trunk diameter on an annual basis for 3 (orchard KBC) or 4 years (orchards GRA and WZB). In the first year of growth, the increase in total shoot length was determined. Subsequently, shoot growth was determined by measuring one of the 1-year-old shoots per tree from each of the center eight trees within a replicate. Growers pruned the leaders in the first overwintering year, and therefore, the increase in leader length could not be determined beyond the initial year.

Yield. The orchard sites differed in their first year of fruit bearing, with orchard GRA having an initial fruit yield in the fourth growing season, whereas orchards WZB and KBC had an initial fruit harvest in the third growing season. For each orchard, 2 years of yield data were obtained. The yield was determined by harvesting and weighing fruits from the center eight trees in each replicate, and values are expressed as kilograms of fruit per tree.

Relative percentage increases in trunk diameter and yield. To obtain an indication of the severity of ARD and the yield gain obtained in each orchard by managing ARD, the relative percentage increases in trunk diameter and yield were calculated, respectively. Only one management treatment, which performed the best (see below) across the three orchards, was selected for this purpose. The relative percentage increase in trunk diameter at each orchard was defined by the increase in trunk diameter of the Pic33-1,3D fumigant/semiselectives treatment (the best-performing treatment across the three orchards) compared with that attained by trees cultivated in nontreated soil after 3 years of growth. This was calculated as follows: (trunk diameter increment of fumigant-containing treatment - trunk diameter increment control) $\div$ trunk diameter increment control $\times 100$. The relative percentage increase in yield was calculated in a similar manner for each orchard.
Root sample collection. Root sampling was conducted 20 months after planting at a distance of 20 to $40 \mathrm{~cm}$ from the trunk on opposite sides of the tree row to a depth of $30 \mathrm{~cm}$. Roots were sampled from 3 trees in the center of the 10-tree plots for each replicate. Roots from the three trees were pooled into one sample, and each root sample was divided into two groups for (i) quantitative polymerase chain reaction (qPCR) quantification of ARD microbial pathogens and (ii) nematode analysis.

qPCR quantification of ARD microbial pathogens from roots. qPCR assays were used to assess the DNA quantity in tree roots of the genus Phytophthora, Cylindrocarpon-like fungi, P. sylvaticum, $P$. vexans, $P$. irregulare, $P$. ultimum, and $R$. solani AG-5. For all qPCR assays, standard curves were established. A gBlock fragment was used for constructing the $R$. solani AG-5 standard curve. The gBlock fragment, synthesized by Integrated DNA Technologies Inc., consisted of a 131-bp fragment that matched the sequence base pairs (44 to $175 \mathrm{bp}$ ) of $R$. solani AG-5 Genbank accession number JQ946296. The synthesized gBlock fragment was dissolved in TE buffer (Integrated DNA Technologies Inc.) to a final concentration of $1.568 \times 10^{12}$ copies per $1 \mu \mathrm{l}$, which was fivefold serially diluted to a concentration of 2.56 copies per $1 \mu \mathrm{l}$, yielding 14 points for the standard curve. For the remaining pathogens, standard curves were constructed using genomic DNA. Isolates of the different species were obtained from the Stellenbosch University culture collection. One isolate each of $P$. cactorum (STEU 7204), P. vexans (STEU 6741), P. irregulare (STEU 7193), P. ultimum (STEU 2187), P. sylvaticum (STEU 7199), and Cylindrocarpon macrodidymum was grown in pea broth (Goodwin et al. 1994). The mycelia harvested from the broth cultures were lyophilized, and $\sim 20 \mathrm{mg}$ mycelia was powdered in 2-ml tubes each containing 0.5 -g glass beads ( $2 \mathrm{~mm}$ ) by shaking for $10 \mathrm{~min}$ in a Retsch MM301 mixer mill. DNA was extracted from the powdered mycelia using the NucleoSpin PLANT II kit (Macherey-Nagel GmbH and Ko) according to the manufacturer's instructions. Extraction buffer PL1 was used, and in the last step, DNA was eluted by applying two 50- $\mu$ l aliquots of elution buffer. The genomic DNA was quantified using a Nanodrop spectrophotometer (ND1000; Nanodrop Technologies). A standard curve for each pathogen was constructed from fivefold serial dilutions of genomic DNA, which yielded 8 to 12 DNA concentration points for the various standard curves depending on the pathogen: $P$. cactorum, $11.37 \mathrm{ng}$ to $5.83 \mathrm{fg}$ (10 points); $P$. vexans, $24.76 \mathrm{ng}$ to $12.6 \mathrm{fg}$ (10 points); $P$. sylvaticum, $35.8 \mathrm{ng}$ to $18.8 \mathrm{fg}$ (10 points); $P$. irregulare, $26.6 \mathrm{ng}$ to $0.54 \mathrm{fg}$ (12 points); $P$. ultimum, $3.7 \mathrm{ng}$ to $47 \mathrm{fg}$ (8 points); and C. macrodydima, $13.56 \mathrm{ng}$ to $6.90 \mathrm{fg}$ (10 points). The standard curve qPCR reactions for the genus $P h y$ tophthora, Cylindrocarpon-like fungi, $P$. sylvaticum, $P$. irregulare, and $R$. solani AG-5 were Syber Green-based reactions. The Kapa Syber fast qPCR master mix (Sigma-Aldrich, SA) was used to a final concentration of $1 \times$ in a final reaction volume of $20 \mu \mathrm{l}$. For each of the various qPCR reactions, the primers, primer concentrations, and additional magnesium chloride added to reactions are shown in Table 3. Syber Green amplifications consisted of an initial denaturation at $95^{\circ} \mathrm{C}$ for 5 min followed by 40 cycles of denaturing at $95^{\circ} \mathrm{C}$ for $10 \mathrm{~s}$, the relevant annealing temperature and times (Table 3), and extension at $72^{\circ} \mathrm{C}$ for $20 \mathrm{~s}$. The exception was the $P$. cactorum assay, which used a $27-$ s extension time. Amplifications were conducted in a Rotor-Gene 6000 machine (Qiagen $\mathrm{GmbH}$ ). Standard curve reaction concentrations were all assayed in triplicate. All assays included a nontemplate water control.

Table 2. Soil properties of orchards where apple replant disease management options were investigated

\begin{tabular}{|c|c|c|c|c|c|c|c|c|}
\hline Orchard $^{x}$ & pH & Classification & Resistance $(\mathrm{Ohm})^{\mathrm{y}}$ & $\operatorname{CEC}(\mathrm{Cmol}[+] / \mathbf{k g})^{\mathbf{y}}$ & Clay $(\%)$ & Silt (\%) & Sand $(\%)$ & Water-holding capacity $(\mathbf{m m} / \mathbf{m})^{\mathbf{z}}$ \\
\hline Orchard GRA & 5.2 & Clay loam & 200 & 10.09 & 39 & 38 & 23 & 59.55 \\
\hline Orchard WZB & 5.4 & Sandy loam & 1,400 & 17.46 & 13 & 20 & 67 & 109.20 \\
\hline Orchard KBC & 4.8 & Sandy loam & 790 & 8.68 & 19 & 14 & 67 & 94.92 \\
\hline
\end{tabular}

${ }^{x}$ GRA, Grabouw; KBC, Koue Bokkeveld; WBZ, Witzenberg valley.

${ }^{y}$ Cation-exchange capacity $(\mathrm{CECs})(\mathrm{Cmol}[+] / \mathrm{kg})$ are the total exchangeable cations, a measure of the soil's ability to retain and supply nutrients, specifically the positively charged nutrient ions called cations. These include the cations calcium, magnesium, potassium, and ammonium and many of the micronutrients.

${ }^{\mathrm{z}}$ Water-holding capacity (millimeters per meter) is the depth of water held between field capacity and permanent wilting point per meter depth of soil. 
The $P$. vexans and $P$. ultimum $\mathrm{qPCR}$ assays were probe-based assays. The primers and probes, which were labeled with 6-carboxyfluorescein (6-FAM) and an Iowa Black dark quencher, are shown in Table 3, and were synthesized by Integrated DNA Technologies Inc. The qPCR reactions consisted of the Kapa probe mastermix (Sigma-Aldrich) at a final concentration of $1 \times$ in a total reaction volume of $20 \mu \mathrm{l}$. The primer and probe concentrations used for each of the qPCR reactions are shown in Table 3. The qPCR amplification consisted of denaturation at $95^{\circ} \mathrm{C}$ for 5 min followed by 40 cycles of denaturation at $95^{\circ} \mathrm{C}$ for $10 \mathrm{~s}$ and annealing/extension temperature and times as indicated in Table 3. Amplifications were conducted in a Rotorgene, with each standard curve concentration assayed in triplicate.

All pathogen standard curves generated were linear $\left(R^{2}=0.98\right.$ to 0.99). The reaction efficiencies, M-slope values, and limits of detection for all assays are shown in Table 3.

DNA was extracted from the fine feeder roots $(\sim 70 \mathrm{mg})$ of trees. The root samples were placed into 2-ml tubes for lyophilization. The lyophilized roots were fragmented using a sterile plastic pestle, and a subsample of $20 \mathrm{mg}$ was used for DNA extraction. DNA was extracted by first powdering the roots in 2-ml tubes using 0.5 -g glass beads $(2 \mathrm{~mm})$ and shaking for $10 \mathrm{~min}$ in a Retsch MM301 mixer mill. DNA was extracted using the NucleoSpin PLANT II kit (Macherey-Nagel GmbH and Ko) according to the manufacturer's instructions as described above for the extraction of DNA from microbial mycelial cultures.

Quantification of ARD pathogens in root DNA extracts was conducted by qPCR using the same reaction and amplification conditions that were used for constructing the standard curves. The root DNA extract was diluted fivefold to eliminate qPCR inhibition that was detected when undiluted DNA was utilized. Each qPCR reaction contained $2 \mu \mathrm{l}$ of the diluted DNA in $20-\mu 1$ reactions, and each sample was assayed in duplicate reactions. Two standard curve control (calibrators) samples were included in all runs, which allowed for the importation of standard curves for pathogen quantification. Pathogen quantities were expressed as absolute pathogen DNA quantities (picograms per milligram ${ }_{\mathrm{DW}}$ ) using the formula

$$
\begin{aligned}
& \text { Absolute pathogen DNA quantity } \\
& =\left(\frac{\text { total volume of extracted genomic DNA } \times \text { dilution factor }}{\text { milligrams of roots used in DNA extraction }}\right)
\end{aligned}
$$

as described by Moein et al. (2019b). Because the Phytophthora qPCR assay is a genus-based assay, the identity of the Phytophthora spp. amplified in qPCR reactions was determined through sequence analysis of the qPCR products (470 bp). This was conducted on three randomly selected root DNA samples from the untreated control samples in each of the trials. The identities of the sequences were determined through BLAST analyses in the Phytophthora-ID database (version 2.0; http://phytophthora-id.org/index.html) (Grünwald et al. 2011).

Nematode extraction and quantification. Approximately $5 \mathrm{~g}$ of washed roots of each replicate treatment, sampled as described above, were sent for parasitic nematode analyses at Nemlab (Durbanville, South Africa). Nematodes were extracted using the centrifugal sugar flotation method (Jenkins 1964).

Apple seedling glasshouse bioassay. Bioassay establishment and treatments. In each orchard, soil samples were collected before treatment applications. Soil samples were collected to a depth of $30 \mathrm{~cm}$ at $\sim 6$ to 10 different sites across the orchard. The soils for each orchard were pooled into one sample. A subset sample of each orchard soil was steam pasteurized for $2 \mathrm{~h}$ at $80^{\circ} \mathrm{C}$ on 2 consecutive days using a Systec Pasteurizer (VE150). The pasteurized soil was ventilated for at least 2 days before use.

Four-week-old cultivar Golden delicious apple seedlings were produced from germinated seed as previously described (Tewoldemedhin et al. 2011a). The 4-week-old seedlings were planted into untreated orchard soil, pasteurized soil, and $15 \%$ untreated soil in pasteurized soil. Each treatment was replicated six times in a completely randomized block design. Each replicate consisted of a 1-liter planting bag containing three apple seedlings. The length and weight of seedlings were recorded just after and before planting.

Seedlings were grown for 3 months under glasshouse conditions of $26 \pm 2{ }^{\circ} \mathrm{C}$ and a humidity range of 60 to $70 \%$. Irrigation was applied according to seedling size; during the first month, 2-min cycles were applied twice a day using a drip irrigation system, resulting in $200 \mathrm{ml}$ per bag a day. From the second month onward, two 5-min irrigation cycles were used daily, which were equivalent to $500 \mathrm{ml}$ of water applied per bag; $100 \mathrm{ml}$ of water-soluble classic Multifeed (Plaaskem, Pty Ltd) fertilizer was applied every 10 days to each planting bag. The Multifeed fertilizer contained nitrogen $(90 \mathrm{~g} / \mathrm{kg})$, phosphorous $(82 \mathrm{~g} / \mathrm{kg})$, potassium $(158 \mathrm{~g} / \mathrm{kg})$, manganese $(900 \mathrm{mg} / \mathrm{kg})$, zinc (350 mg/kg), boron $(1,000 \mathrm{mg} / \mathrm{kg})$, molybdenum $(70 \mathrm{mg} / \mathrm{kg})$, iron $(750 \mathrm{mg} / \mathrm{kg})$, manganese $(300 \mathrm{mg} / \mathrm{kg})$, and copper $(75 \mathrm{mg} / \mathrm{kg})$. Foliar pathogens and pests were managed on a 2-week basis by applying Agromectin EC (abamectin: $18 \mathrm{~g}$ a.i./liter; Arysta LifeScience Pvty Ltd), Arcastin Flo (cyhexatin: $600 \mathrm{~g}$ a.i./liter; Sipcam Southern Africa Pty Ltd), Topaz 200 EW (penconazole: 200 g a.i./liter; Syngenta Pty Ltd), Nimrod EC (bupirimate: $250 \mathrm{~g}$ a.i./liter; Makhteshim-Agan SA Pty, Limited), and Mospilan 20 SL (acetamiprid: 222 g a.i./liter; Plaaskem Pty Ltd) using a laboratory spray bottle.

Table 3. Real-time quantitative polymerase chain reaction (PCR) primers, probes, and amplification conditions used for quantifying apple replant disease microbial pathogens (Pythium irregulare, Phytopythium vexans, Pythium ultimum, the genus Phytophthora, Pythium sylvaticum, and Cylindrocarpon-like fungi)

\begin{tabular}{|c|c|c|c|c|c|c|c|c|c|c|}
\hline \multirow{3}{*}{$\frac{\text { Target species }}{\text { P. sylvaticum }}$} & & & \multirow{3}{*}{$\frac{\text { Probe }(\mathbf{n M})}{-}$} & \multicolumn{2}{|c|}{ Annealing $x$} & \multirow{3}{*}{$\begin{array}{c}\mathbf{M g C l}_{2} \mathbf{y} \\
500 \\
\mathrm{nM}^{\mathrm{z}}\end{array}$} & \multirow{3}{*}{$\begin{array}{c}\text { Efficiency } \\
0.93\end{array}$} & \multirow{3}{*}{$\begin{array}{c}\begin{array}{c}\text { M } \\
\text { slope }\end{array} \\
-3.3\end{array}$} & \multirow{3}{*}{$\begin{array}{c}\begin{array}{c}\text { Limit of } \\
\text { detection (fg } \\
\text { per reaction) }\end{array} \\
18.8 \mathrm{fg}\end{array}$} & \multirow{3}{*}{$\begin{array}{l}\text { Reference } \\
\text { Schroeder et al. } \\
2006\end{array}$} \\
\hline & \multicolumn{2}{|c|}{ Primers (nM) } & & Temperature & Time & & & & & \\
\hline & Syl1F (200) & Syl1R (200) & & 65 & $15^{z}$ & & & & & \\
\hline P. irregulare & PirF1 (300) & PirR1 (900) & - & 60 & 5 & $\begin{array}{l}100 \\
\mathrm{nM}^{\mathrm{z}}\end{array}$ & 0.96 & -3.4 & $0.54 \mathrm{fg}$ & Spies et al. 2011 \\
\hline $\begin{array}{l}\text { Genus } \\
\quad \text { Phytophthora }\end{array}$ & Yph1F $(250)^{z}$ & $\mathrm{Yph} 2 \mathrm{R}(250)^{\mathrm{z}}$ & - & 62 & $20^{\mathrm{z}}$ & - & 1 & -3.10 & $5.80 \mathrm{fg}$ & Schena et al. 2008 \\
\hline P. ultimum & PulF2 (300) & PulR2 (300) & PulP2 (150) & & & - & 0.98 & -3.5 & $47.0 \mathrm{fg}$ & Spies et al. 2011 \\
\hline P. vexans & PV390P (300) & PV455P (300) & PV412P (200) & & & - & 0.95 & -3.4 & $12.6 \mathrm{fg}$ & Moein et al. 2019b \\
\hline $\begin{array}{l}\text { Cylindrocarpon- } \\
\text { like fungi }\end{array}$ & YT1F (300) & CylR (300) & - & & & $300 \mathrm{nM}$ & 0.92 & -3.2 & $6.90 \mathrm{fg}$ & $\begin{array}{l}\text { Tewoldemedhin } \\
\text { et al. 2011a }\end{array}$ \\
\hline $\begin{array}{l}\text { Rhizoctonia } \\
\text { AG5 }\end{array}$ & $\begin{array}{l}\text { RSAG5F } \\
\quad(900)\end{array}$ & $\begin{array}{l}\text { RSAG5R } \\
\text { (300) }\end{array}$ & - & 60 & 15 & & 0.98 & -3.4 & $\begin{array}{l}2.56 \\
\text { copies }\end{array}$ & $\begin{array}{r}\text { Mazzola and } \\
\text { Zhao } 2010\end{array}$ \\
\hline
\end{tabular}
from apple roots

${ }^{x}$ Annealing temperatures and extension times used in assays. All assays were Syber Green based, with the exception of the P. ultimum and $P$. vexans assays, which were probe based.

${ }^{y}$ The qPCR master mix used in all assays contained a final concentration of $2.5 \mathrm{mM} \mathrm{MgCl}_{2}$, and therefore, most assays did not require additional $\mathrm{MgCl}_{2}$, except for the P. sylvaticum and P. irregulare assays.

${ }^{\mathrm{z}}$ Values were modified from the published assay. 
Seedling growth assessments. After 3 months, the lengths and weights of seedlings were determined, and the increases in length and plant fresh weight (shoots and roots) were determined. Plant growth data from the untreated control and the pasteurized treatments were used to calculate the percentage increase in length or weight for each orchard. Relative increase in plant growth assessments was determined as described above.

Isolation and identification of oomycetes. Oomycetes were isolated from the washed roots of seedlings that had been cultivated in the untreated orchard soils. Twenty feeder roots were plated from each replicate bag onto PARP medium (Jeffers and Martin 1986), to which $0.8 \mathrm{ml} /$ liter Benomyl (500 g benlate per $1 \mathrm{~kg}$; Villa Crop Protection) was added to suppress Zygomycete fungal growth. Plates were incubated at room temperature for 2 to 3 days. Hyphal tips emerging from roots were transferred to potato dextrose agar (Biolab Diagnostics) amended with $0.04 \mathrm{~g} /$ liter streptomycin, and plates were incubated for 3 to 7 days at $25^{\circ} \mathrm{C}$. After a pure culture was confirmed, fungal mycelium was scraped from the plates, and DNA was extracted using a slightly modified cetrimonium bromide (CTAB) method (Lee and Taylor 1990).

Oomycete isolates were first grouped into polymerase chain reaction (PCR)-restriction fragment-length polymorphism (RFLP) groups. The internal transcribed spacer (ITS) region was amplified as previously described (Tewoldemedhin et al. 2011b), and the PCR products were digested using a double-enzyme restriction digest containing HinfI and HhaI (Mazzola et al. 2009). DNA fragments were separated on $3 \%$ agarose gels containing ethidium bromide, and fragments were visualized under ultraviolet illumination. Isolates that yielded similar PCR-RFLP patterns were placed in the same PCR-RFLP group. The PCR products of isolates representing the different PCR-RFLP groups were sequenced by the Central Analytical Facility at Stellenbosch University. The identity of the sequences was determined by BLAST analyses in GenBank (https:// www.ncbi.nlm.nih.gov/Genbank/). For Pythium species identification, only reference sequences submitted by Levesque and de Cock (2004) or published sequences of described new species were utilized. Phytophthora sequences were submitted to the Phytophthora-ID database Version 2.0 (http://phytophthora-id.org/index.html) for species identification (Grünwald et al. 2011).

Nematode quantification and qPCR quantification of ARD marker microbial pathogens. Nematodes and microbial pathogens were quantified from the fine feeder roots of seedlings from each replicate bag (one planting bag containing three seedlings) as described above.

Statistical analyses. Tree growth data (shoot length and increase in trunk diameter), yield, pathogen DNA quantities, and ARD severity estimates (percentage increase in seedling growth in the bioassay trial; in the orchard trials, the trunk diameter and yield) were subjected to an analysis of variance using the General Linear Models Procedure of SAS statistical software (Version 9.4; SAS Institute Inc.). The Shapiro-Wilk test was used to test for deviation from normality (Shapiro and Francia 1972). The pathogen DNA concentration data deviated significantly from normality, and therefore, the data were $\ln (x+1)$ transformed, resulting in the data being normally distributed. Fisher's least significant difference test was calculated at the 95\% confidence level to separate means for significant effects. Levene's variance ratio test was used to calculate variation within replications (Levene 1960). Pearson correlation analyses were conducted on (i) increase in trunk diameter and shoot length, (ii) ARD causative agents and tree growth (shoot length and increase in trunk diameter) and yield, and (iii) ARD causative agents with each other using XLStat (Version 2014; Addinsoft).

\section{Results}

Orchard trials. Tree growth. In the final year of tree growth measurement (year 3 or 4), in all three orchards, the applied treatments yielded significantly higher increases in trunk diameter and shoot length than the untreated control (Table 4). There were, in general, no significant differences between the applied treatments for shoot

Table 4. The effect of various soil fumigation and semiselective chemical treatments on apple tree growth (shoot length and increase in trunk diameter) and yield in three apple replant disease orchard trials ${ }^{\mathrm{w}}$

\begin{tabular}{|c|c|c|c|c|}
\hline Orchards & Treatments $^{\mathrm{x}}$ & $\begin{array}{c}\text { Increase in shoot length }(\mathrm{cm}) \text { in } \\
\text { the third or fourth year of } \\
\text { growth }^{y}\end{array}$ & $\begin{array}{c}\text { Increase in trunk } \\
\text { diameter (mm) } 3 \text { or } 4 \\
\text { years postplanting }\end{array}$ & $\begin{array}{l}\text { 2-Year cumulative yield } \\
\text { (kg per tree) }\end{array}$ \\
\hline Orchard GRA & Untreated control & $39.05 \mathrm{c}$ & $30.35 \mathrm{c}$ & $11 \mathrm{c}$ \\
\hline Orchard GRA & Pic33-1,3D & $65.42 \mathrm{ab}$ & $39.86 \mathrm{ab}$ & $17.69 \mathrm{abc}$ \\
\hline Orchard GRA & Pic57-1,3D & $62.86 \mathrm{ab}$ & $41.86 \mathrm{ab}$ & $21.38 \mathrm{ab}$ \\
\hline Orchard GRA & Methyl bromide & $68.18 \mathrm{a}$ & $42.75 \mathrm{a}$ & $24.08 \mathrm{a}$ \\
\hline Orchard GRA & Independent semiselectives & $61.25 \mathrm{ab}$ & $37.83 \mathrm{~b}$ & $17.06 \mathrm{bc}$ \\
\hline Orchard GRA & Pic33-1,3D plus semiselectives & $60.36 \mathrm{~b}$ & $39.37 \mathrm{ab}$ & $18.64 \mathrm{ab}$ \\
\hline Orchard GRA & $P$ value & $<0.0001$ & $<0.0001$ & 0.0360 \\
\hline Orchard WZB & Untreated control & $38.32 \mathrm{~b}$ & $14.30 \mathrm{c}$ & $1.62 \mathrm{~b}$ \\
\hline Orchard WZB & Pic33-1,3D & $72.78 \mathrm{a}$ & $20.54 \mathrm{ab}$ & $1.53 \mathrm{~b}$ \\
\hline Orchard WZB & Pic57-1,3D & $62.91 \mathrm{a}$ & $20.83 \mathrm{ab}$ & $1.79 \mathrm{~b}$ \\
\hline Orchard WZB & Methyl bromide & $68.14 \mathrm{a}$ & $21.62 \mathrm{ab}$ & $3.47 \mathrm{ab}$ \\
\hline Orchard WZB & Independent semiselectives & $63.43 \mathrm{a}$ & $19.64 \mathrm{~b}$ & $1.87 \mathrm{~b}$ \\
\hline Orchard WZB & Pic33-1,3D plus semiselectives & $65.13 \mathrm{a}$ & $25.10 \mathrm{a}$ & $4.21 \mathrm{a}$ \\
\hline Orchard WZB & $P$ value & $<0.0001$ & 0.0018 & 0.0228 \\
\hline Orchard KBC & Untreated control & $20.48 \mathrm{~b}$ & $22.16 \mathrm{~b}$ & $14.35 \mathrm{c}$ \\
\hline Orchard KBC & Pic33-1,3D & $38.15 \mathrm{a}$ & $27.60 \mathrm{a}$ & $29.77 \mathrm{~b}$ \\
\hline Orchard KBC & Pic57-1,3D & $38.22 \mathrm{a}$ & $29.48 \mathrm{a}$ & $37.36 \mathrm{a}$ \\
\hline Orchard KBC & Independent semiselectives & $35.46 \mathrm{a}$ & $27.37 \mathrm{a}$ & $28.81 \mathrm{~b}$ \\
\hline Orchard KBC & Pic33-1,3D plus semiselectives & $35.78 \mathrm{a}$ & $28.94 \mathrm{a}$ & $37.36 \mathrm{a}$ \\
\hline Orchard KBC & Pic57-1,3D plus semiselectives & $39.29 \mathrm{a}$ & $29.07 \mathrm{a}$ & $35.78 \mathrm{a}$ \\
\hline Orchard KBC & $P$ value & $<0.0001$ & 0.0045 & $<0.0001$ \\
\hline
\end{tabular}

\footnotetext{
${ }^{w}$ Values in columns are the average of six replicates (eight trees per replicate). For each orchard, values within a column followed by the same letter do not differ significantly $(P>0.05)$ according to Fisher's least significant difference test. Pic33-1,3D, 33.3\% chloropicrin and 60.8\% 1,3-dichloropropene; Pic57-1,3D, $57 . \%$ chloropicrin and $38 \% 1,3$ dichloropropene.

$x$ The semiselective treatments consisted of a soil drench applied at planting (metalaxyl, fenamiphos, and imidacloprid) followed by 3 years of potassium phosphonate applications. The fumigant treatments were all applied preplant. Two of the fumigants differed in their chloropicrin content; the Pic 33-1,3D fumigant had $33.3 \%$ chloropicrin and 60.8\% 1,3-dichloropropene, whereas the Pic57-1,3D fumigant had 57.\% chloropicrin and 38\% 1,3 dichloropropene.

y Shoot lengths for orchards Witzenberg valley (WZB) and Grabouw (GRA), which were planted in 2013, were taken in the fourth year of growth, whereas in the orchard Koue Bokkeveld (KBC), which was planted in 2014, shoot length was taken in the third year of growth.

${ }^{\mathrm{z}}$ Increases in trunk diameter values are for a 4-year period (2013 to 2017) for orchards WZB and GRA and a 3-year period for orchard KBC (2014 to 2017 ).
} 
length and increase in trunk diameter. The exceptions for increase in trunk diameter were for the independent semiselectives treatment: (i) a significantly lower increase in trunk diameter was recorded relative to the methyl bromide treatment at orchard GRA, and (ii) in orchard WZB, a significantly lower increase in trunk diameter was evident relative to the Pic33-1,3D/semiselective treatment. For shoot length, the only applied treatment that had a significantly lower shoot length than the other treatments was the Pic33-1,3D treatment/ semiselectives treatment, which had a significantly lower shoot length than the methyl bromide treatment at the GRA orchard (Table 4).

Yield. Not all of the applied treatments were consistent across the three orchards in significantly increasing yields relative to the untreated control (Table 4). The Pic33-1,3D/semiselectives treatment was the only treatment that resulted in a significant increase in yield relative to the untreated control in all three orchard trials. Pic57-1,3D significantly increased cumulative yields relative to the untreated control in two orchards (orchards GRA and KBC), whereas the methyl bromide treatment only did so in one of the two orchards where it was applied. Pic33-1,3D and the independent semiselectives treatments only resulted in significantly higher cumulative yields than the untreated control in the KBC orchard.

In some orchards, there were significant differences in cumulative yield between the Pic57-1,3D and Pic33-1,3D treatments and when semiselectives were added to these treatments (Table 4). Pic57-1,3D resulted in a significantly higher cumulative yield relative to Pic33$1,3 \mathrm{D}$ only in orchard $\mathrm{KBC}$. The addition of semiselective chemicals to Pic33-1,3D resulted in significantly higher cumulative yields relative to the fumigant-only treatment in two of the orchards (WZB and KBC). The combined effect of Pic57-1,3D and the semiselectives was only evaluated in one orchard, where yield was not significantly increased.

In orchards GRA and WZB, preplant methyl bromide soil fumigation did not result in significantly higher cumulative yields relative to either of the Pic-1,3D fumigation treatments (Table 4).
Relative percentage increases in trunk diameter and yield. The relative percentage increase in trunk diameter between the untreated control and the Pic33-1,3D/semiselectives treatment after 3 years of growth varied in the three orchards (Table 5). The WZB orchard had a significantly higher relative percentage increase in trunk diameter than the KBC orchard (Table 5).

There were no significant differences $(P=0.0982)$ in the relative percentage increase in yield between the three orchards. The highest increase in cumulative yield was observed in orchard $\mathrm{KBC}$ (160.42\%) followed by orchard WZB $(158.72 \%)$ and lastly, orchard GRA $(63.54 \%)$ (Table 5).

qPCR quantification of ARD microbial pathogens from roots. qPCR assays successfully detected several of the ARD microbial pathogens in roots of apple cultivated at the three orchard replant sites (Table 6). Cylindrocarpon-like spp., $P$. cactorum, and $P$. irregulare were detected in all three orchards. Although a genus-specific Phytophthora spp. assay was used, the Phytophthora species involved was identified as $P$. cactorum for all three trial sites through sequence analyses of a subset of the qPCR amplicons obtained from root DNA samples. P. ultimum was only detected in orchards GRA and WZB. P. sylvaticum, $P$. vexans, and $R$. solani AG-5 were not detected in root DNA samples obtained from any of the orchard sites (Table 6).

Significant differences $(P \leq 0.0338)$ in the quantity in Cylindrocarponlike spp. DNA in root samples were detected between the control and applied treatments at all three orchards (Table 6). The KBC orchard was the only orchard where the significant difference was because of treatments causing a reduction in Cylindrocarpon-like root DNA relative to the untreated control; tree roots from the Pic57-1,3D (14.35 $\left.\mathrm{pg} / \mathrm{mg}_{\mathrm{DW}}\right)$ and the Pic33-1,3D/semiselective $\left(11,30 \mathrm{pg} / \mathrm{mg}_{\mathrm{DW}}\right)$ treatments had significantly lower DNA quantities of Cylindrocarpon-like spp. than the untreated control $\left(62.25 \mathrm{pg} / \mathrm{mg}_{\mathrm{DW}}\right)$. In contrast, roots of trees cultivated in methyl bromide-treated soil in orchard GRA had a

Table 5. Apple replant disease (ARD) severity and ARD microbial pathogens in three ARD soils evaluated under glasshouse conditions and under orchard conditions ${ }^{\mathrm{u}}$

\begin{tabular}{|c|c|c|c|c|c|c|c|}
\hline \multirow[b]{2}{*}{ Orchard } & \multicolumn{4}{|c|}{ Apple seedling glasshouse bioassays } & \multicolumn{3}{|c|}{ Orchard trials } \\
\hline & $\begin{array}{l}\text { \% Increase } \\
\text { seedling } \\
\text { weight }^{\mathbf{v}}\end{array}$ & $\begin{array}{l}\text { \% Increase } \\
\text { seedling } \\
\text { length }^{\mathbf{v}}\end{array}$ & 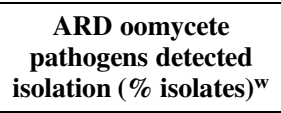 & $\begin{array}{l}\text { ARD pathogens detected } \\
\text { qPCR }\left(\mathrm{pg} / \mathrm{mg}_{\mathrm{DW}}\right)^{\mathrm{x}}\end{array}$ & $\begin{array}{c}\% \text { Increase } \\
\text { trunk } \\
\text { diametery }^{y}\end{array}$ & $\begin{array}{l}\% \text { Increase } \\
\text { yieldy }^{\mathbf{y}}\end{array}$ & $\begin{array}{l}\text { ARD pathogens } \\
\text { detected qPCR }\end{array}$ \\
\hline$\overline{\text { GRA }}$ & $106.71 \mathrm{~b}$ & $54.31 \mathrm{~b}$ & P. cactorum $(100 \%)$ & $\begin{array}{l}\text { P. cactorum }(0.009), \\
P . \text { irregulare }(0.006), \\
P . \text { ultimum }(0.0006), \\
\text { Cylindrocarpon like } \\
(0.184), P . \text { vexans } \\
(4.02)\end{array}$ & $42.78 \mathrm{ab}$ & 63.54 & $\begin{array}{l}\text { P. cactorum }(40.330), \\
\text { P. irregulare }(3.960), \\
\text { P. ultimum }(0.002), \\
\text { Cylindrocarpon like } \\
(12.430)\end{array}$ \\
\hline WZB & $63.28 \mathrm{c}$ & $65.45 \mathrm{~b}$ & $\begin{array}{l}\text { P. irregulare }(43 \%), \\
\text { P. ultimum }(57 \%)\end{array}$ & $\begin{array}{l}\text { P. cactorum }(0.004), \\
\text { P. irregulare }(0.12), \\
\text { P. ultimum }(0.016), \\
\text { Cylindrocarpon like } \\
(0.700), \text { P. vexans } \\
(0.484)\end{array}$ & $63.98 \mathrm{a}$ & 158.72 & $\begin{array}{l}\text { P. cactorum }(34.00), \\
\text { P. irregulare }(0.028), \\
\text { P. ultimum }(0.068), \\
\text { Cylindrocarpon like } \\
(1.300)\end{array}$ \\
\hline KBC & $185.79 \mathrm{a}$ & $180.33 \mathrm{a}$ & $\begin{array}{l}\text { P. irregulare } \\
\quad(21.4 \%), \text { Pythium } \\
\text { sp. B2A }(64.2 \%), \\
\text { P. heterothallicum } \\
(14.2 \%)\end{array}$ & $\begin{array}{l}\text { P. cactorum }(0.002), \\
\text { P. irregulare }(0.084), \\
\text { P. ultimum }(0.007), \\
\text { Cylindrocarpon like } \\
(0.3435)\end{array}$ & $30.62 \mathrm{~b}$ & 160.42 & $\begin{array}{l}\text { P. cactorum }(0.370), \\
\text { P. irregulare }(0.040), \\
\text { Cylindrocarpon like } \\
(12.450)\end{array}$ \\
\hline$P$ value & $<0.0001$ & 0.0004 & & & 0.0417 & 0.0982 & \\
\hline
\end{tabular}

u Pathogens listed are Pythium irregulare, Phytopythium vexans, Pythium ultimum, Phytophthora cactorum, Pythium heterothallicum. GRA, Grabouw; KBC, Koue Bokkeveld; WBZ, Witzenberg valley.

$\checkmark$ The percentage increase was calculated as follows: pasteurized treatment - untreated control)/pasteurized treatment $\times 100$.

${ }^{w}$ ARD microbial pathogens were obtained in a glasshouse study from the roots of apple seedlings grown in untreated soil. The percentages of the isolates that each species represented of all of the oomycetes isolates obtained are shown in parentheses.

$x$ The quantity of microbial ARD pathogens detected in apple seedling roots of the untreated control using quantitative polymerase chain reaction (qPCR) analysis. The amount of pathogen DNA is indicated in parentheses as $\mathrm{pg} / \mathrm{mg}$ dry weight (DW) of roots.

y Percentage increase in trunk diameter was calculated for the third year of growth for all orchards as follows: (increase in trunk diameter of the low chloropicrin fumigant combined with semiselective treatment - increase in trunk diameter of the untreated control)/increase in trunk diameter of the $33.3 \%$ chloropicrin and 60.8\% 1,3-dichloropropene fumigant combined with semiselective treatment $\times 100$. The percentage increase in yield was calculated in a similar manner except that the cumulative yield of the relevant treatments was used.

$\mathrm{z}$ The ARD microbial pathogens detected in orchard tree roots of the control treatment using qPCR. The amount of pathogen DNA detected using qPCR is shown in parentheses. 
significantly higher Cylindrocarpon-like spp. concentration (195.70 $\left.\mathrm{pg} / \mathrm{mg}_{\mathrm{DW}}\right)$ than the untreated control $\left(62.150 \mathrm{pg} / \mathrm{mg}_{\mathrm{DW}}\right)$. In orchard WZB, three treatments had significantly higher Cylindrocarpon-like DNA quantities than the untreated control. These included Pic331,3D, Pic57-1,3D, and independent use of semiselective treatments (Table 6).

$P$. irregulare DNA quantities in tree roots were only significantly different between treatments in orchard WZB $(P=0.0197)$ (Table 6). However, the differences were not because of a reduction in pathogen quantity in treatments relative to the untreated control. The Pic57$1,3 \mathrm{D}$ treatment had a significantly higher $P$. irregulare concentration $\left(5.89 \mathrm{pg} / \mathrm{mg}_{\mathrm{DW}}\right)$ than the untreated control $\left(0.140 \mathrm{pg} / \mathrm{mg}_{\mathrm{DW}}\right)$.

P. ultimum DNA concentrations detected in apple roots in orchards GRA and WZB were low $\left(<0.340 \mathrm{pg} / \mathrm{mg}_{\mathrm{DW}}\right)$, and the pathogen was not detected in root samples from the KBC orchard (Table 6). There were no significant treatment effects $(P>0.1795)$ in the quantity of $P$. ultimum DNA detected in tree root samples from the GRA and WZB orchards.

The quantity of $P$. cactorum DNA detected in tree roots differed significantly among treatments at the GRA and KBC $(P<0.0090$ or 0.0008 ) orchards. In orchard GRA, all of the applied treatments with the exception of the Pic33-1,3D and methyl bromide fumigation treatments possessed significantly lower $P$. cactorum root DNA concentrations than the no treatment control. In orchard KBC, the quantity of $P$. cactorum DNA detected in the root samples from the untreated control was significantly higher than that detected for all other treatments (Table 6).

Nematode extraction and quantifications. Pratylenchus spp. was the only plant parasitic nematode genus identified in root samples from the study orchards. Pratylenchus spp. infestations were observed in orchards WZB and KBC but not in orchard GRA (Table 6). Pratylenchus spp. root densities were significantly different among treatments only at the WZB orchard $(P=0.0260)$. At the
WZB orchard, all treatments significantly reduced Pratylenchus spp. root densities ( $<47 / 5-\mathrm{g}$ roots) relative to the control (548/5-g roots).

Correlation between tree growth and yield with ARD causative agent quantities. Tree growth (shoot and trunk diameters) and/or yield in some of the orchards had a significant negative correlation with root DNA quantities of $P$. cactorum and $P$. ultimum, and Pratylenchus spp. root densities (Table 7). There were no significant correlations between $P$. irregulare and Cylindrocarpon-like fungal DNA quantities detected in tree roots and relative tree growth (data not shown).

The importance of $P$. cactorum in limiting tree performance at all three orchards was evident from several significant negative correlations between $P$. cactorum DNA quantities in tree roots and certain tree growth parameters and yield (Table 7). In all three orchards, there were significant negative correlations $(r=-0.340$ to -0.632 ; $P<0.042$ ) between shoot length and $P$. cactorum root DNA quantities in the third and sometimes, fourth year of growth. Increase in trunk diameter was significantly negatively correlated with $P$. cactorum root DNA quantities in all orchards in the third year of growth $(r=-0.333$ to $-0.410 ; P<0.047)$. Yield was only significantly negatively correlated with $P$. cactorum root DNA quantities in orchard $\mathrm{KBC}(r=-0.455 ; P=0.005)$ (Table 7$)$.

$P$. ultimum root DNA quantities only showed negative correlations with tree growth in orchard WZB. The contribution of P. ultimum to disease development at the WZB orchard was evidenced by the significant negative correlation between the quantity of pathogen DNA detected in tree roots and increase in trunk diameter in the third year of growth $(r=-0.458 ; P=0.030)$ (Table 7).

In orchards WZB and KBC, significant negative correlations were observed between Pratylenchus spp. root densities and tree growth or yield (Table 7). In orchard WZB, shoot length and increase in trunk diameter were significantly correlated with Pratylenchus spp. root densities in the third and fourth year of growth $(r=-0.393$ to

Table 6. The effect of various soil fumigation and semiselective chemical treatments on the DNA quantities of apple replant disease pathogens (Cylindrocarponlike fungi, Pythium irregulare, Pythium ultimum, and Phytophthora cactorum) and Pratylenchus spp. densities in the roots of apple trees in three apple replant disease orchard trials ${ }^{\mathrm{z}}$

\begin{tabular}{|c|c|c|c|c|c|}
\hline Orchards and treatments & $\begin{array}{c}\begin{array}{c}\text { Cylindrocarpon-like fungi } \\
\left(\mathbf{p g} / \mathrm{mg}_{\mathrm{DW}}\right)\end{array}\end{array}$ & $\begin{array}{c}P . \text { irregulare } \\
\left(\mathrm{pg} / \mathrm{mg}_{\mathrm{DW}}\right)\end{array}$ & $\begin{array}{l}\text { P. ultimum } \\
\text { (pg/mg }\end{array}$ & $\begin{array}{l}\text { P.cactorum } \\
\left(\mathbf{p g} / \mathbf{m g}_{\mathrm{DW}}\right)\end{array}$ & $\begin{array}{l}\text { Pratylenchus spp. } \\
\quad \text { (5-g roots) }\end{array}$ \\
\hline \multicolumn{6}{|l|}{ Orchard GRA } \\
\hline Untreated control & $62.150 \mathrm{~b}$ & 19.8 & 0.010 & $201.650 \mathrm{a}$ & ND \\
\hline Pic33,1,3D & $50.700 \mathrm{~b}$ & 5.9 & 0.015 & $107.495 \mathrm{abc}$ & ND \\
\hline Pic57-1,3D & $57.250 \mathrm{~b}$ & 0.025 & 0.140 & $0.000 \mathrm{c}$ & ND \\
\hline Methylbromide & $195.700 \mathrm{a}$ & 0.900 & 0.200 & $101.400 \mathrm{ab}$ & ND \\
\hline Independent semiselectives & $54.250 \mathrm{~b}$ & 2.500 & 0.015 & $0.000 \mathrm{c}$ & ND \\
\hline Pic33-1,3D plus semiselectives & $36.950 \mathrm{~b}$ & 2.200 & 0.025 & $54.550 \mathrm{bc}$ & ND \\
\hline$P$ value & 0.0172 & 0.1518 & 0.744 & 0.0090 & ND \\
\hline \multicolumn{6}{|l|}{ Orchard WZB } \\
\hline Untreated control & $6.500 \mathrm{bc}$ & $0.140 \mathrm{~b}$ & 0.340 & 170.00 & $548 \mathrm{~b}$ \\
\hline Pic33,1,3D & $18.950 \mathrm{ab}$ & $0.150 \mathrm{~b}$ & 0.095 & 30.450 & $47 \mathrm{a}$ \\
\hline Pic57-1,3D & $54.850 \mathrm{ab}$ & $5.890 \mathrm{a}$ & 0.075 & 16.450 & $42 \mathrm{a}$ \\
\hline Methylbromide & $6.050 \mathrm{bc}$ & $0.060 \mathrm{~b}$ & 0.015 & 3.650 & $75 \mathrm{a}$ \\
\hline Independent semiselectives & $24.000 \mathrm{ab}$ & $0.150 \mathrm{~b}$ & 0.035 & 18.600 & $30 \mathrm{a}$ \\
\hline Pic33-1,3D plus semiselectives & $0.950 \mathrm{c}$ & $0.205 \mathrm{~b}$ & 0.010 & 12.750 & $10 \mathrm{a}$ \\
\hline$P$ value & 0.0338 & 0.0197 & 0.1795 & 0.3273 & 0.0260 \\
\hline \multicolumn{6}{|l|}{ Orchard $\mathrm{KBC}$} \\
\hline Untreated control & $62.250 \mathrm{a}$ & 0.200 & ND & $1.850 \mathrm{a}$ & 231 \\
\hline Pic 33,1,3D & $18.250 \mathrm{a}$ & 0.050 & ND & $0.000 \mathrm{~b}$ & 95 \\
\hline Pic57-1,3D & $14.350 \mathrm{~b}$ & 0.150 & ND & $0.350 \mathrm{~b}$ & 31 \\
\hline Independent semiselectives & $109.600 \mathrm{a}$ & 0.150 & ND & $0.000 \mathrm{~b}$ & 70 \\
\hline Pic33-1,3D plus semiselectives & $11.300 \mathrm{~b}$ & 0.100 & ND & $0.300 \mathrm{~b}$ & 21 \\
\hline Pic57-1,3D plus semiselectives & $62.250 \mathrm{a}$ & 0.150 & ND & $0.050 \mathrm{~b}$ & 50 \\
\hline$P$ value & 0.0019 & 0.4832 & ND & 0.0008 & 0.5339 \\
\hline
\end{tabular}

${ }^{\mathrm{z}}$ Root samples used for pathogen and Pratylenchus spp. quantification were obtained 20 months after planting. Sampling was conducted at a distance of 20 to 40 $\mathrm{cm}$ from the tree trunk on opposite sides of the tree at a depth of $30 \mathrm{~cm}$. Pathogen quantities are expressed as picograms of pathogen DNA per milligram of dry weight (DW) of root, which were determined through quantitative polymerase chain reaction analyses. Values in columns are the average of six replicates. For each replicate, roots sampled from three trees were pooled into one sample. For each orchard, values in columns followed by the same letter do not differ significantly according to Fisher's least significance difference test at the 95\% significance level. ND indicates that the organisms were not detected. Pythium sylvaticum, Pythium vexans, and Rhizoctonia solani AG-5 were not detected in any of the orchards. GRA, Grabouw; KBC, Koue Bokkeveld; Pic33-1,3D, 33.3\% chloropicrin and 60.8\% 1,3-dichloropropene; Pic57-1,3D, 57.\% chloropicrin and 38\% 1,3 dichloropropene; WBZ, Witzenberg valley. 
$-0.516 ; P<0.042)$. Additionally, in orchard KBC, Pratylenchus spp. root densities were significantly correlated with yield $(r=-0.433$; $P=0.008$ (Table 7).

Correlation between different ARD causative agent quantities. Correlation analyses between the different microbial pathogen DNA root quantities and Pratylenchus spp. root densities yielded interesting associations in two orchards. Significant positive correlations were evident between $P$. cactorum root DNA quantities and Pratylenchus spp. root densities at orchard WZB $(r=0.942 ; P<$ $0.0001)$ and orchard KBC $(r=0.43 ; P=0.009)$. The quantity of Cylindrocarpon-like spp. DNA detected in tree roots was positively correlated with $P$. irregulare root DNA quantity $(r=0.714 ; P<$ $0.0001)$ at the WZB orchard and $P$. ultimum $(r=0.432 ; P=0.009)$ at orchard GRA.

Apple seedling glasshouse bioassay. Seedling growth assessments. For all three orchard soil bioassay trials, there were significant differences between the untreated control and pasteurized and 15\% diluted soil treatments for length $(P<0.01389)$ and weight $(P<0.01389)$ (Supplementary Table S1). The pasteurized soil significantly enhanced seedling length and weight relative to the untreated control soil in all three orchard trial soils.

The relative percentage increase in seedling weight and height in response to pasteurization differed among the three orchard soils (Table 5). Pasteurization of the KBC orchard soil resulted in significantly higher percentage increases in seedling growth (180.33 and $185.79 \%$ in weight and length, respectively) than the WZB and GRA orchard soils. The relative percentage increase in seedling weight was significantly lower in the WZB orchard relative to the other two orchards.

Isolation and $q P C R$ identification of oomycetes. Isolations from roots of seedlings cultivated in certain orchard soils revealed the presence of additional oomycete species beyond those identified through qPCR analyses (Table 5). This was owing to the fact that only a limited number of oomycete species were included in qPCR analyses. In orchard KBC, isolation studies revealed the presence of Pythium heterothallicum (14.2\% of isolates) and Pythium sp. complex B2A (64.2\% of isolates). In all three orchards, qPCR analyses from seedling roots in the bioassay revealed a few additional oomycete pathogens than those that were detected in the orchard tree roots (Table 5). In orchards GRA and WZB, this consisted of $P$. vexans DNA. In orchard KBC, $P$. ultimum DNA was detected in seedling roots but not orchard tree roots.

$q P C R$ identification of Cylindrocarpon-like spp. In all three orchard soils, Cylindrocarpon-like spp. were identified in the roots of the bioassay seedlings, similar to what was observed in the orchard trial tree roots (Table 5).

Nematode extraction and quantifications. The genus Pratylenchus was the only plant parasitic nematode genus identified in the seedling roots. The seedling roots grown in orchards WZB and KBC had relatively high Pratylenchus spp. root densities of 250 and 590 per $5 \mathrm{~g}$ of roots, respectively. Orchard GRA had a very low Pratylenchus spp. seedling root density (10/5-g roots), which is consistent with Pratylenchus spp. not recovered from tree roots collected at this orchard site.

\section{Discussion}

In this study, several treatments were evaluated for the management of ARD in three apple replant orchards (GRA, WZB, and $\mathrm{KBC})$ situated in different production regions in South Africa. All treatments, including the fumigants Pic33-1,3D, Pic57-1,3D, and methyl bromide, a semiselective chemical mixture (metalaxyl, imidacloprid, fenamiphos, and potassium phosphonate) applied independently or combined with Pic-1,3D fumigants, improved tree growth (shoot length and increased in trunk diameter) to a similar level that was significantly higher than that of the untreated control. Although the semiselective chemical treatment used independently did not consistently improve tree growth performance to the level of methyl bromide, it was as effective as the two Pic-1,3D fumigants (Pic33-1,3D and Pic57-1,3D). The latter fumigants are currently the standard ARD management practice available to growers in South Africa (Kapp et al. 2016).

Cumulative yield data were more useful for distinguishing differences in efficacy among the evaluated treatments. However, relative cumulative yield responses of any given treatment differed among the three orchards, making it difficult to identify the bestperforming treatment. The Pic33-1,3D fumigant combined with semiselectives was the most consistent treatment in improving cumulative yield relative to the untreated control in all orchard trials. In the WZB orchard, all soil fumigation treatments failed to significantly increase cumulative yields. This is most likely because of the inability of the fumigants to affect ARD inoculum that was present in the numerous undecomposed tree roots that were present in the orchard soil at the time of fumigation. In the WZB orchard, the fumigants were applied in the same year in which the old orchard trees were removed, which did not provide enough time for the decomposition of tree roots. The two Pic-1,3D fumigants resulted in cumulative yields that were similar to those attained in response to methyl bromide fumigation, but the treatments differed in efficacy from each other. Based on this study, the Pic57-1,3D formulation is considered a superior option to Pic33-1,3D for ARD management, because it resulted in (i) a significantly greater cumulative yield than Pic33-1,3D in the $\mathrm{KBC}$ orchard and (ii) a significant increase in cumulative yield relative to the untreated control in the GRA orchard, whereas Pic33-1,3D did not. The higher chloropicrin concentration in the Pic55-1,3D fumigant most likely contributed to improved control of ARD causative fungi and oomycetes. The formulation, however, still contains enough 1,3-dichlorpropene for lesion nematode suppression as encountered at the $\mathrm{KBC}$ orchard. There are no other studies that have specifically compared $33.3 \%$ chloropicrin-containing fumigant formulations with $57 \%$ chloropicrin-containing fumigant formulations for the management of ARD or replant disease on other tree crops. The preponderance of ARD studies have used Pic-1,3D formulations

Table 7. Pearson correlation analyses between apple tree growth parameters (shoot length and increase in trunk diameter) and yield with DNA quantities of apple replant disease microbial pathogens (Phytophthora cactorum and Pythium ultimum) in tree roots and Pratylenchus spp. root densities in three apple ARD orchard trials. ${ }^{\mathrm{z}}$

\begin{tabular}{|c|c|c|c|c|c|}
\hline \multirow[b]{3}{*}{ Orchard } & \multicolumn{5}{|c|}{ Pearson correlation coefficient ( $P$ value $)$} \\
\hline & \multicolumn{2}{|c|}{ Third-year tree growth } & \multicolumn{2}{|c|}{ Fourth-year tree growth } & \multirow[b]{2}{*}{ Cumulative yield } \\
\hline & Increase trunk diameter & Shoot length & Increase trunk diameter & Shoot length & \\
\hline \multicolumn{6}{|l|}{ P. cactorum } \\
\hline Orchard GRA & $-0.358(0.032)$ & $-0.340(0.042)$ & NS & $-0.355(0.034)$ & NS \\
\hline Orchard WZB & $-0.410(0.030)$ & $-0.413(0.029)$ & NS & $-0.452(0.016)$ & $-0.455(0.005)$ \\
\hline Orchard KBC & $-0.333(0.047)$ & $-0.632(<0.001)$ & ND & ND & NS \\
\hline \multicolumn{6}{|l|}{ P. ultimum } \\
\hline Orchard WZB & $-0.458(0.03)$ & NS & NS & NS & NS \\
\hline \multicolumn{6}{|l|}{ Practylenchus spp. } \\
\hline Orchard WZB & $-0.49(0.009)$ & $-0.49(0.009)$ & $-0.393(0.042)$ & $-0.516(0.006)$ & NS \\
\hline Orchard KBC & NS & NS & NS & NS & $-0.433(0.008)$ \\
\hline
\end{tabular}

${ }^{\mathrm{z}}$ GRA, Grabouw; KBC, Koue Bokkeveld; ND, not done; NS, nonsignificant; WBZ, Witzenberg valley. 
containing either 35 or $17 \%$ chloropicrin (Braun et al. 2010; Mazzola and Brown 2010; Parker et al. 2014; Rumberger et al. 2004).

Investigations into the causative agents associated with orchard tree roots indicated that several agents were often present. However, the DNA root quantities or densities of only a few were consistently negatively correlated with tree growth or yield. P. cactorum, P. irregulare, and Cylindrocarpon-like fungi were associated with tree roots in all three trials. Pratylenchus spp. and P. ultimum were associated with tree roots in two orchards. A previous study in South Africa reported that $P$. cactorum, $P$. ultimum, $P$. irregulare, and Cylindrocarpon-like fungal DNA were present in all of the investigated ARD orchards, whereas Pratylenchus spp. occurred in 67\% of the orchards (Tewoldemedhin et al. 2011c). Worldwide Pratylenchus spp. are known to be associated inconsistently with ARD orchard soils (Mazzola and Manici 2012). Based on correlation analyses between causative agent quantities and tree growth and yield, $P$. cactorum contributed to disease development at all three orchards. This was also true in the two orchards where Pratylenchus spp. (WZB and $\mathrm{KBC}$ ) were present but only in one orchard where $P$. ultimum occurred in tree roots.

The effect of the various treatments on ARD causative agents was also investigated by determining if the treatments incited a significant reduction in quantities relative to the untreated control. A 20-month postplant timepoint was selected, because several of the treatments consisted of the application of semiselective chemicals. The latter included the use of phosphonate applications until 3 years postplant. At the 20-month sampling point, three of the five sets of phosphonate applications were completed. There were only a few cases where treatments significantly reduced ARD causative agents in roots relative to roots from the nontreated soil. These involved $P$. cactorum (orchards KBC and GRA), Pratylenchus spp. (orchard $\mathrm{KBC}$ ), and Cylindrocarpon-like fungi (orchard KBC; Pic57,-13D and Pic33-1,3D/semiselectives treatment). The suppression of $P$. cactorum and Pratylenchus spp. by the independent use of semiselectives was evident in all of the aforementioned orchards. It is likely that an earlier timepoint could have revealed a clearer indication of the specific effect of the soil fumigant treatments on the ARD causative agents. ARD is known to affect trees within the first year of growth (Mazzola and Manici 2012). Furthermore, the effect of fumigants has previously been reported to not extend beyond 1 year postplant (Auvil et al. 2011), and Pythium spp. and Pratylenchus spp. can recolonize the fumigated tree row within 1 year postplant (Mazzola et al. 2015). The results from this study suggest that this is not always the case for all ARD soils because the effect of fumigants on some ARD causative agents were still evident 20 months postplant.

Synergistic interactions between ARD causative agents and their effect on treatment efficacy and tree growth are also important to consider. For example, it has been reported that $P$. irregulare and Cylindrocarpon-like fungi act synergistically to cause ARD (Braun 1991; Tewoldemedhin et al. 2011c). In this study, a significant positive correlation was documented between Cylindrocarpon-like spp. and $P$. irregulare or P. ultimum in two orchards, supporting the synergistic interaction between these two groups of organisms. Thus, although no significant correlation was observed between tree growth and root infection by $P$. irregulare, which has previously been reported to be highly virulent (Tewoldemedhin et al. 2011b), and Cylindrocarpon-like fungi, these pathogens likely did contribute to ARD severity but in a manner unrelated to their root DNA quantities per se. This is also supported by a report indicating that no correlation existed between apple seedling stunting and $P$. irregulare root DNA quantities and root colonization under glasshouse conditions (Moein et al. 2019b). In these orchard trials, the significant positive correlation between $P$. cactorum root DNA quantities and Pratylenchus spp. root densities suggests the potential for a synergistic interaction in orchards where they cooccur. This has previously been reported for replant disease occurring in red raspberry (Gigot et al. 2013) and the tobacco/Phytophthora parasitica Dastur/Pratylenchus brachyurus (Godfrey 1929) Filpjev \& Schuurmans Stekhoven 1941 system (Inagaki and Powell 1969). It is likely that wounds caused by Pratylenchus spp. facilitate infection by Phytophthora spp. (Inagaki and Powell 1969). In other systems, however, nematode infections were reported to negatively affect Phytophthora spp. infections. This was observed in the tobacco/P. parasitica/Pratylenchus penetrans system (Mc Intyre and Miller 1978) and the citrus/Tylenchulus semipenetrans Cobb 1913/Phytophthora nicotianae Breda de Haan system (El-Borai et al. 2002).

A few important causative agents that were not investigated in this study in orchard tree roots might have also influenced treatment efficacy. In the KBC orchard, P. heterothallicum and Pythium complex B2A might have been involved, because they were recovered from roots of seedlings cultivated in this soil in the glasshouse bioassay study. Pythium sp. complex B2A is a species complex that includes several species (Pythium dissotocum, Pythium coloratum, Pythium lutarium, Pythium marinum, Pythium diclinum, Pythium aff. dictyosporum, and Pythium sp. group F and P. sp. tumidum) that cannot be differentiated based on ITS sequence data (Robideau et al. 2011). Among these listed species, $P$. dissotocum and $P$. coloratum have been identified as pathogens of apple (Braun 1995; Sewell 1981; Tewoldemedhin et al. 2011b). In orchards GRA and WZB, P. vexans might also have been functioning as a causative agent, because it was detected in glasshouse seedling roots but not in orchard tree roots. $P$. vexans has previously been reported to occur in established apple tree roots in South Africa and incite disease on apple seedlings (Tewoldemedhin et al. 2011b, 2011c). Future studies should further investigate the pathogenicity of $P$. vexans toward 1-year apple trees and its occurrence at an earlier timepoint postplant under orchard conditions. Although several binucleate Rhizoctonia groups, such as AG-I, AG-F, AG-G, and AG-Q, in general have low relative virulence (Mazzola 1997; Tewoldemedhin et al. 2011a), some isolates of AG-G, which do occur in South Africa (Tewoldemedhin et al. 2011a, 2011c), can be highly virulent (Mazzola et al. 2015). The quantities of binucleate Rhizoctonia groups in tree roots thus also warrant investigation in the future.

This is the first study to show that the independent use of semiselective chemicals can consistently improve tree growth in ARD orchards and cumulative yield to a lesser extent. Cumulative yield was only significantly increased in the $\mathrm{KBC}$ orchard, and it was not increased to a level that was equivalent to that attained with fumigants. The semiselectives in some instances when combined with the Pic33-1,3D fumigant can furthermore significantly increase cumulative yields in comparison with the independent use of the fumigant. The efficacy of semiselective chemicals might be twofold: owing to the suppression of ARD causative agents associated with planting material or the prevention of pathogen reinfestation of the fumigated tree row. ARD causative agents are known to be associated with planting material in South Africa (Moein et al. 2019).

The only other study that has investigated the potential of metalaxyl and fosetyl-Al (alkyl phosphonate) for managing ARD was a study by Autio et al. (1991) in Massachusetts, U.S.A. The products were reported to not be highly effective when applied independently during the first year of growth, because a significant increase in trunk and shoot growth was only observed in the first year and not in the subsequent two growing seasons. The short-lived performance in the efficacy of the treatments was most likely because of ARD causative agents continuing to affect tree growth in the second year. Therefore, chemical applications must not only be made in the first year. In this study, phosphonates were applied until 3 years postplant. Another study that supports the efficacy of metalaxyl in reducing ARD severity comes from observations that the application of a mefenoxam soil drench to a Brassicae napus seed meal treatment can significantly improve apple tree growth and yield in ARD orchards provided that $P$. penetrans was not present (Mazzola and Brown 2010; Mazzola and Mullinix 2005).

The mode of action of the semiselective chemicals and the relative importance of the different compounds in the mixture will be difficult to determine. It will furthermore not be productive to evaluate whether each chemical can single handily control ARD, because ARD is known to be a disease complex that cannot be controlled using single products. This was clearly shown by Mazzola and Brown (2010), where single Brassicacea seed meal product applications were ineffective in suppressing ARD pathogens; only certain 
mixtures of Brassicacea species seed meals were effective. It is reasonable to expect that the metalaxyl, phosphonates, and fenamiphos are most likely involved in suppression of oomycetes and Pratylenchus spp., because they are known to function in this manner. Whether imidaclorpid, applied for woolly apple aphid control, played a role in suppressing the ARD agents is unknown, but it cannot be excluded. Imidaclorpid is also known as a resistance inducer on citrus against bacterial diseases when applied at the correct dosage (Francis et al. 2009). Phosphonates are also increasingly being seen as plant resistance inducers (Jackson et al. 2000; Massoud et al. 2012). Future studies can, therefore, investigate the effect of the semiselective mixture on the induction of host plant defense responses of apple roots challenged with the ARD causative agents. Host plant defense induction is known to be important in ARD disease suppression (Shin et al. 2016; Weiss et al. 2017).

In summary, the study showed that, considering all of the unknown variabilities associated with ARD orchard sites, the best management option consisted of fumigation with Pic33-1,3D combined with semiselective chemicals. Because the Pic57-1,3D fumigant was superior in a few instances to the Pic33-1,3D fumigant, growers should in the future use Pic57-1,3D. The effect of combining the latter fumigant with semiselective chemicals is currently uncertain, because this treatment was only evaluated in one trial, where it did not provide a benefit in cumulative yield. Considering the high levels of ARD causative agents present in South African plant material (Moein et al. 2019a), the addition of semiselective chemicals to trees on fumigated soil might furthermore be warranted. The inclusion of fenamiphos in the semiselective mixture is problematic, because this nematicide is likely to be lost from the South African market in the near future, such as has occurred internationally. Therefore, future studies should investigate the inclusion of alternative nematicides, such as fluapyram (Bayer), in the mixture.

\section{Literature Cited}

Autio, W. R., Greene, D. W., Cooley, D. R., and Schupp, J. R. 1991. Improving the growth of newly planted apple trees. Hortic. Sci. 26:840-843.

Auvil, T. D., Schmidt, T. R., Hanrahan, I., Castillo, F., McFerson, J. R., and Fazio, G. 2011. Evaluation of dwarfing rootstocks in Washington apple replant sites. Acta Hortic. 903:265-271.

Braun, P. G. 1991. The combination of Cylindrocarpon lucidum and Pythium irregulare as a possible cause of apple replant disease in Nova Scotia. Can. J. Plant Pathol. 13:291-297.

Braun, P.G. 1995. Effects of Cylindrocarpon and Pythium species on apple seedlings and potential role in apple replant disease. Can. J. Plant Pathol. 17: 336-341.

Braun, P. G., Fuller, K. D., McRae, K., and Fillmore, A. E. 2010. Response of 'Honeycrisp ${ }^{\circledR}$ ' apple trees to combination of pre-plant fumigation, deep ripping, and hog manure compost incorporation in a soil with replant disease. HortScience 45:1702-1707.

Cabral, A., Groenewald, J. Z., Rego, C., Oliveira, H., and Crous, P. W. 2012. Cylindrocarpon root rot: Multi-gene analysis reveals novel species within the Ilyonectria radicicola species complex. Mycol. Prog. 11:655-688.

Cabrera, J. A., Hanson, B. D., Gerik, J. S., Gao, S., Qin, R., and Wang, D. 2015. Pre-plant soil fumigation with reduced rates under low permeability films for nursery production, orchard and vineyard replanting. Crop Prot. 75:34-39.

Chaverri, P., Salgado, C., Hirooka, Y., Rossman, A. Y., and Samuels, G. J. 2011. Delimitation of Neonectria and Cylindrocarpon (Nectriaceae, Hypocreales, Ascomycota) and related genera with Cylindrocarpon-like anamorphs. Stud. Mycol. 68:57-78.

Dullahide, S. R., Stirling, G. R., Nikulin, A., and Stirling, A. M. 1994. The role of nematodes, fungi, bacteria, and abiotic factors in the etiology of apple replant problems in the Granite Belt of Queensland. Aust. J. Exp. Agric. 34:1177-1182.

El-Borai, F. E., Duncan, L. W., and Graham, J. H. 2002. Infection of citrus roots by Tylenchulus semipenetrans reduced root infection by Phytophthora nicotianae. J. Nematol. 34:384-389.

Francis, M. I., Redondo, A., Burns, J. K., and Graham, J. H. 2009. Soil application of imidacloprid and related SAR-inducing compounds produces effective and persistent control of citrus canker. Eur. J. Plant Pathol. 124:283-292.

Gigot, J. A., Walters, T. W., and Zasda, I. A. 2013. Impact and occurrence of Phytophthora rubi and Pratylenchus penetrans in commercial red raspberry (Rubus idaeus) fields in Northwestern Washington. Int. J. Fruit Sci. 13:357-372.

Goodwin, S. B., Cohen, B. A., and Fry, W. E. 1994. Panglobal distribution of a single clonal lineage of the Irish potato famine fungus. PNAS 91:11591-11595.

Grünwald, N. J., Martin, F. N., Larsen, M. M., Sullivan, C. M., Press, C. M., Coffey, M. D., Hansen, E. M., and Parke, J. L. 2011. Phytophthora-ID. org: A sequence-based Phytophthora identification tool. Plant Dis. 95:337-342.
Inagaki, H., and Powell, N. T. 1969. Influence of the root lesion nematode on black shank symptom development in flue-cured tobacco. Phytopathology 10:1350-1355.

Jackson, T. J., Burgess, T., Colquhoun, I., and Hardy, G. S. 2000. Action of the fungicide phosphite on Eucalyptus marginata inoculated with Phytophthora cinnamomi. Plant Pathol. 49:147-154.

Jaffee, B. A., Abawi, G. S., and Mai, W. F. 1982a. Fungi associated with roots of apple seedlings grown in soil from an apple replant site. Plant Dis. 66:942-944.

Jaffee, B. A., Abawi, G. S., and Mai, W. F. 1982b. Role of soil microflora and Pratylenchus penetrans in an apple replant disease. Phytopathology 72: 247-251.

Jeffers, S. N., and Martin, S. B. 1986. Comparison of two media selective for Phytophthora and Pythium species. Plant Dis. 70:1038-1043.

Jenkins, W. R. 1964. A rapid centrifugal-flotation technique for separating nematodes from soil. Plant Dis. Rep. 48:692.

Kapp, C., Addison, M.F., Storey, S.G. and Malan, A.P. 2016. Nematode indicators for soil health monitoring of the orchard of the future at Oak Valley. SAFJ Oct/ Nov:80-85.

Lee, S. B., and Taylor, J. W. 1990. Isolation of DNA from fungal mycelia and single spores. Pages 282-287 in: PCR Protocols: A Guide to Methods and Applications. M. A. Innis, D. H. Gelfand, J. S. Sninsky, and T. J. White, eds. Academic Press, New York.

Levene, H. 1960. Robust tests for equality of variances. Contr. Stat. 1:278-292.

Levesque, C. A., and De Cock, A. W. A. M. 2004. Molecular phylogeny and taxonomy of the genus Pythium. Mycol. Res. 108:1363-1388.

Locascio, S. J., Gilreath, J. P., Dickson, D. W., Kucharek, T. A., Jones, J. P., and Noling, J. W. 1997. Fumigant alternatives to methyl bromide for polyethylenemulched tomato. HortScience 32:1208-1211.

Lombard, L., Van Der Merwe, N. A., Groenewald, J. Z., and Crous, P. W. 2014. Lineages in Nectriaceae: Re-evaluating the generic status of Ilyonectria and allied genera. Phytopathol. Mediterr. 53:515-532.

Manici, L. M., Ciavatta, C., Kelderer, M., and Erschbaumer, G. 2003. Replant problems in South Tyrol: Role of fungal pathogens and microbial population in conventional and organic apple orchards. Plant Soil 256:315-324.

Manici, L. M., Kelderer, M., Caputo, F., and Mazzola, M. 2015. Auxin-mediated relationships between apple plants and root inhabiting fungi: Impact on root pathogens and potentialities of growth-promoting populations. Plant Pathol 64:843-851.

Manici, L. M., Kelderer, M., Caputo, F., Sacca, M. L., Nicoletti, F., Topp, A. R., and Mazzola, M. 2018. Inovolvement of Cactylonectria and Ilyonextria spp. in tree decline affecting multiogeneration apple orchards. Plant Soil 425:217-230.

Manici, L. M., Kelderer, M., Franke-Whittle, I. H., Ruhmer, T., Baab, G., Nicoletti, F., Caputo, F., Topp, A., Insam, H., and Naef, A. 2013. Relationship between root-endophytic microbial communities and replant disease in specialized apple growing areas in Europe. Appl. Soil Ecol. 72:207-214.

Massoud, K., Barchietto, T., Le Rudulier, T., Pallandre, L., Didierlaurent, L., Garmier, M., Ambard-Bretteville, F., Seng, J. M., and Saindrenan, P. 2012. Dissecting the phosphite-induced priming in Arabidopsis infected with Hyaloperonospora arabidopsidis. Plant Physiol. 159:286-298.

Mazzola, M. 1997. Identification and pathogenicity of Rhizoctonia spp. isolated from apple roots and orchard soils. Phytopathology 87:582-587.

Mazzola, M. 1998. Elucidation of the microbial complex having a causal role in the development of apple replant disease in Washington. Phytopathology 88: 930-938.

Mazzola, M., Andrews, P. K., Reganold, J. P., and Levesque, C. A. 2002. Frequency, virulence, and metalaxyl sensitivity of Pythium spp. isolated from apple roots under conventional and organic production systems. Plant Dis. 86:669-675.

Mazzola, M., and Brown, J. 2010. Efficacy of brassicaceous seed meal formulations for the control of apple replant disease in conventional and organic production systems. Plant Dis. 94:835-842.

Mazzola, M., Brown, J., Zhao, X., Izzo, A. D., and Fazio, G. 2009. Interaction of brassicaceous seed meal and apple rootstock on recovery of Pythium spp. and Pratylenchus penetrans from roots grown in replant soils. Plant Dis. 93: 51-57.

Mazzola, M., Granatstein, D. M., Donald, C. E., and Mullinx, K. 2001. Suppression of specific apple root pathogens by Brassica napus seed meal amendment regardless of glucosinolate content. Phytopathology 91:673-679.

Mazzola, M., Hewavitharana, S. S., and Strauss, S. L. 2015. Brassica seed meal soil amendments transform the rhizosphere microbiome and improve apple production through resistance to pathogen reinfestation. Phytopathology 105: 460-469.

Mazzola, M., and Manici, L. M. 2012. Apple replant disease: Role of microbial ecology in cause and control. Annu. Rev. Phytopathol. 50:45-65.

Mazzola, M., and Mullinix, K. 2005. Comparative field efficacy of management strategies containing Brassica napus seed meal or green manure for the control of apple replant disease. Plant Dis. 89:1207-1213.

Mazzola, M., and Zhao, X. 2010. Brassica juncea seed meal particle size influences chemistry but not soil biology-based suppression of individual agents inciting apple replant disease. Plant Soil 337:313-324.

Mc Intyre, J. L., and Miller, P. M. 1978. Protection of tobacco against Phytophthora parasitica var. nicotianae by cultivar-nonpathogenic races, cell-free sonicates and Pratylenchus penetrans. Phytopathology 68:235-239. 
Moein, S., Mazzola, M., Ntushelo, N. S., and McLeod, A. 2019a. Apple nursery trees and irrigation water as potential external inoculum sources of apple replant disease in South Africa. Eur. J. Plant Pathol. https://doi.org/10.1007/ s10658-018-01631-9

Moein, S., Mazzola, M., Spies, C. F. J., and McLeod, A. 2019b. Evaluating different approaches for the quantification of oomycete apple replant pathogens, and their relationship with seedling growth reductions. Eur. J. Plant Pathol. https://doi.org/10.1007/s10658-018-01652-4

Parker, M. L., Hoyt, T., and Clark, B. 2014. Evaluating apple replant strategies in the Southeastern United States. Acta Hortic. 1058:645-650.

Rabie, I., Denamn, S., and Cook, N. C. 2001. Apple replant disease: alternatives to methyl bromide. Decid. Fruit Grow. 51:29-32.

Robideau, G. P., De, Arthur, W., Coffey, M. D., Voglmayr, H., Brouwer, H., Bala, K., Chitty, D. W., Désaulniers, N., Eggertson, Q. A., and Gachon, C. M. 2011. DNA barcoding of oomycetes with cytochrome $\mathrm{c}$ oxidase subunit I and internal transcribed ARD r. Mol. Ecol. Resour. 11:1002-1011.

Rumberger, A., Yao, S., Merwin, I. A., Nelson, E. B., and Thies, J. E. 2004. Rootstock genotype and orchard replant position rather than soil fumigation or compost amendment determine tree growth and rhizosphere bacterial community composition in an apple replant soil. Plant Soil 264: 247-260.

Schena, L., Duncan, J. M., and Cooke, D. E. L. 2008. Development and application of a PCR-based 'molecular tool box'for the identification of Phytophthora species damaging forests and natural ecosystems. Plant Pathol. 57:64-75.

Schroeder, K. L., Okubara, P. A., Tambong, J. T., Lévesque, C. A., and Paulitz, T. C. 2006. Identification and quantification of pathogenic Pythium spp. from soils in eastern Washington using real-time polymerase chain reaction. Phytopathology 96:637-647.

Sewell, G. W. F. 1981. Effects of Pythium species on the growth of apple and their possible causal role in apple replant disease. Ann. Appl. Biol. 97:31-42.

Shapiro, S. S., and Francia, R. S. 1972. An approximate analysis of variance test for normality. J. Am. Stat. Assoc. 67:215-216.

Shin, S. B., Zheng, P., Fazio, G., Mazzola, M., Main, D., and Zhu, Y. M. 2016. Transcriptome changes specifically associated with apple (Malus domestica) root defense response during Pythium ultimum infection. Physiol. Mol. Plant Pathol. 94:16-26.

Spies, C. F. J., Mazzola, M., and McLeod, A. 2011. Characterisation and detection of Pythium and Phytophthora species associated with grapevines in South Africa. Eur. J. Plant Pathol. 131:103-119.

Stirling, G. R., Dullahide, S. R., and Nikulin, A. 1995. Management of lesion nematode (Pratylenchus jordanensis) on replanted apple trees. Aust. J. Exp. Agric. 35:247-258

Tewoldemedhin, Y., Mazzola, M., Mostert, L., and McLeod, A. 2011a Cylindrocarpon species associated with apple tree roots in South Africa and their quantification using real-time PCR. Eur. J. Plant Pathol. 129:637-651.

Tewoldemedhin, Y. T., Mazzola, M., Botha, W. J., Spies, C. F. J., and McLeod, A 2011b. Characterization of fungi (Fusarium and Rhizoctonia) and oomycetes (Phytophthora and Pythium) associated with apple orchards in South Africa. Eur. J. Plant Pathol. 130:215-229.

Tewoldemedhin, Y. T., Mazzola, M., Labuschagne, I., and McLeod, A. 2011c. A multiphasic approach reveals that apple replant disease is caused by multiple biological agents, with some agents acting synergistically. Soil Biol. Biochem. 43:1917-1927.

Utkhede, R., and Smith, E. 1995. Control of Phytophthora crown and root rot of apple trees with fosetyl-aluminium in new plantings. Pest Manag. Sci. 45: 117-122.

Utkhede, R. S. 1987. Control of crown rot (Phytophthora cactorum) of apple trees with the systemic fungicides metalaxyl and fosetyl-aluminium. Pest Manag. Sci. 19:289-295

Weiss, S., Lui, B. Y., Reckwell, D., Beerhues, L., and Winkelmann, T. 2017. Impaired defense reactions in apple replant disease-affected roots of Malus domestica 'M26.' Tree Physiol. 37:1672-1685.

Wesseling, C., Corriols, M., and Bravo, V. 2005. Acute pesticide poisoning and pesticide registration in Central America. Toxicol. Appl. Pharmacol. 207: 697-705.

Yao, S., Merwin, I. A., Abawi, G. S., and Thies, J. E. 2006. Soil fumigation and compost amendment alter soil microbial community composition but do not improve tree growth or yield in an apple replant site. Soil Biol. Biochem. 38:587-599. 